\title{
RESEARCH ON THE EXPRESSION OF SUCROSE SYNTHASE GENE IN SWEET SORGHUM
}

\author{
GAO, H. C. ${ }^{1}$ - Hussain, K. ${ }^{2}-$ PANG, H. B. ${ }^{1}-$ LI, X. M. ${ }^{1}-$ MA, L. J. ${ }^{1}-$ WANG, L. L. ${ }^{1}-$ \\ ZHANG, Y. - WU, S. W. ${ }^{3}-$ LI, Y. Y. ${ }^{*}$ \\ ${ }^{1}$ College of Life Science, Shenyang Normal University \\ No. 253 Huanghe North Street, Shenyang, Liaoning 110034, China \\ ${ }^{2}$ Department of Botany, University of Gujrat, HH Campus, Gujrat, Pakistan \\ ${ }^{3}$ College of Science Institute, Shenyang Agricultural University \\ No. 120 Dongling Road, Shenyang 110866, China \\ *Corresponding authors \\ e-mail: yueyinglicn@163.com,wusuwen001@126.com
}

(Received $3^{\text {rd }}$ Oct 2018; accepted $5^{\text {th }}$ Dec 2018)

\begin{abstract}
Sucrose synthase is present in all plant tissues. It has an important role in the metabolism of many organizations, especially affecting sucrose metabolism, The higher the gene expression, the higher the sucrose content is. In order to explore the factors affecting the degree of sucrose synthase activity, we selected 10 different varieties of sweet sorghum leaves in different periods and used quantitative PCR (Polymerase Chain Reaction) to determine the cDNA concentration with comparison to a standard curve. In this experiment, the relative expression of the SS gene of HT was compared in different periods. The results showed that there was a difference in the relative expression of the SS gene between different varieties of sweet sorghum.
\end{abstract}

Keywords: sweet sorghum, sucrose synthase (SS), RT-PCR, sucrose content, qualitative analyses

\section{Introduction}

Sweet sorghum originated in Africa, it has strong resistance, high photosynthetic rate, high sugar content, wide adaptability, etc (Gao et al., 2017). It is a variant of ordinary grain sorghum (Wu el at, 2014; Zhang et al., 2012), one of the world's important energy plants (Jiang et al., 2012; Vermerris, 2011). In biomass energy systems, it has the name of "the most efficient solar energy converter" because of the high production capacity (Zhao et al., 2015). Sweet sorghum is a drought-tolerant crop. It has a wide range of root systems, strong water absorption. It can absorb moisture from dry soil. Dry areas are, especially non-glycemic areas, not suitable for growing other sugar crops, Sweet sorghum is a salt-tolerant crop which can be planted on a large scale (Yu et al., 2014). It has wide adaptability to soil $\mathrm{pH}$, in the value range of 5.0-8.0 it can be grown normally (Zhao et al., 2015).

Sweet sorghum is the most powerful competitor in the biomass energy system. It is an excellent new renewable energy crop. Its stems and seeds can be pulverized for the production of ethanol, production costs are half of that as corn (Zhan et al., 2003). Therefore, the study of bio-fuel ethanol from sweet sorghum is carried out by the world. (Zhan el at, 2003; Gnansounou et al., 2005). Sweet sorghum is an important sugar crop. The accumulation of sugar in sweet sorghum is mainly based on sucrose. By comparing the gene expression levels of different varieties at different stages, it is found that increasing the sugar content is important.(Ye et al., 2012). In this experiment, the sweet sorghum leaves of 10 varieties were extracted in 4 periods. 
Reverse transcription was applied to obtain cDNA. Then real-time fluorescence quantitative technology was used to compare the difference of gene expression in sweet sorghum in different periods and varieties. It is important to understand the law of sugar accumulation in sweet sorghum, the principle of sucrose synthesis, metabolism and regulation. It can also serve as a guide for breeding sweet sorghum varieties with high sugar content, production practices and it also has a good reference for other crops.

Sucrose synthase (SS) is a key enzyme among plant sucrose metabolizing enzymes. Sucrose synthase exists in two forms. In the cytoplasm, sucrose synthase exists in a soluble state and is attached to the cell membrane in an insoluble state, but the former is the main way of existence (Chai et al., 2012), sucrose synthase is present in all plant tissues. It has an important role in the metabolism of many organizations. However, its activity in library tissues is higher than that in photosynthetic tissues. The activity of sucrose synthase is the highest in the tissues and cell walls of some synthetic starches (Xue et al., 2009). In sugar cane, studies have shown that the SS gene has a role in facilitating the unloading of sucrose in the organ during transport (Martin et al., 1993). During the synthesis of sucrose in tomato, SS maintains relatively high activity (Qi et al., 2005). The sucrose metabolic pathway has a dominant position in the sugar metabolism of peach (Zhang et al., 2014). At present, the SS gene has been cloned from plants such as sugar cane (Lingle et al., 2001), Arabidopsis (Chopra et al., 1992), corn, and sugar beet (Hesse et al., 1996).

Compared with conventional PCR technology, real-time PCR technology has high sensitivity, specificity, good repeatability, fast and simple operation, and can be directly used for qualitative analysis and quantitative analysis (Liu, 2011). Real-time fluorescence quantitative technology is a very effective experimental method, which has been widely used in the fields of molecular biology, genetic engineering, medical diagnosis, etc. (Ren et al., 2011). In this experiment, by analyzing the correlation between the SS gene and housekeeping gene expression, the dissolution curves of the two genes are single peaks. It shows that during the PCR amplification process, the reaction specificity is good, quantitatively it is accurate, and there is no non-specific amplification and primer dimer, which is the ideal dissolution curve. It explain s that the selected primers can be applied to the relative quantitative analysis and the expression of 10 varieties of sweet sorghum SS gene in 4 growth stages by Comparative Delta-delta $\mathrm{Ct}$ method. If other heterogeneous peaks indicate nonspecific fluorescence, the quantification is inaccurate and subsequent experiments cannot be performed.

\section{Research design and methods}

\section{Plant material}

The experimental materials are 10 varieties of sweet sorghum from China, they were provided by Liaoning Academy of Agricultural Sciences, growing in the experimental field under natural conditions and were Jinxi 53, Sweet GL, LTR108, LTR168, HT, collier, M-81E, Rio, Honey, umbrella. 3 repetitions were selected in the four stages of seedling, jointing, heading and maturity. The materials were taken from the sweet sorghum last 2 leaves. The samples were frozen in liquid nitrogen and placed in a $80{ }^{\circ} \mathrm{C}$ refrigerator (SANYO, MDF-382E). 


\section{Determination of SS activity}

The extraction of the enzyme solution is carried out at $0-4{ }^{\circ} \mathrm{C}, 0.5 \mathrm{~g}$ of sorghum leaves was weighed and placed them in a mortar. Enzyme extract and a small amount of quartz sand were added to it. It was ground thoroughly on ice, then transfer to the centrifuge tube, and at $12000 \mathrm{r} / \mathrm{min}$ it was centrifuged at $4{ }^{\circ} \mathrm{C}$ for $20 \mathrm{~min}$. The supernatant was taken as a crude enzyme solution. $50 \mu \mathrm{L}$ of the crude enzyme solution was transferred into a test tube and $50 \mu \mathrm{L}$ HEPES-NaOH buffer ( $\mathrm{pH}$ 7.5), $20 \mu \mathrm{L} 100 \mathrm{mmol} / \mathrm{L}$ UDPG (uridine diphosphate glucose), $20 \mu \mathrm{L} 100 \mathrm{mmol} / \mathrm{L}$ fructose, $20 \mu \mathrm{L} 50 \mathrm{mmol} / \mathrm{L} \mathrm{MgCl}_{2}$, were added to it. It was put into a $30{ }^{\circ} \mathrm{C}$ water bath for $30 \mathrm{~min} .200 \mu \mathrm{L}$ of $2 \mathrm{mmol} / \mathrm{L} \mathrm{NaOH}$ was added and a water bath was applied at $100{ }^{\circ} \mathrm{C}$ for $10 \mathrm{~min}$. The test tube was cooled in flowing water then hydrochloric acid and resorcinol were added to it and it was shaken well, measured with a spectrophotometer, repeated three times, and averaged.

\section{Total RNA extraction and cDNA synthesis}

It was carried out based on the instruction manual of the RNA extraction kit (Promega Z3100). RNA was extracted from the leaves of 10 varieties of sweet sorghum in 4 periods. The diluted RNA samples were added to a clean cuvette, and their absorbance were read with a nucleic acid quantitation meter (ScanDrop 200) at 260, 280 and $230 \mathrm{~nm}$. If A260/A280 $>1.8, \mathrm{~A} 260 / \mathrm{A} 230>2.0$, it proved that the purity of RNA extracted was qualified and can be used in subsequent experiments. RNA mass concentration calculation: RNA $\mu \mathrm{g} / \mu \mathrm{l}=\mathrm{A} 260 \times$ $33 \times$ Dilution factor/1000. Then RNA products were detected in $1 \%$ agarose gels.

For the synthesis of the first strand of cDNA the RT-PCR (Real-time PCR) kit (TaKaRa RR037A) was used, the reaction system and operation are as follows: The reaction system is $10 \mu \mathrm{L}$ : $5 \times$ PRT Mix $2 \mu \mathrm{L}$, RNA template $8 \mu \mathrm{L}$. The reverse transcription reaction conditions are as follows: $37^{\circ} \mathrm{C} 15 \mathrm{~min}, 85^{\circ} \mathrm{C} 5 \mathrm{~s}$, Reverse transcription products are stored at $-20^{\circ} \mathrm{C}$. Then PCR was used to amplify and detect cDNA: The PCR reaction system is $25 \mu \mathrm{L}: 15.5$ $\mu \mathrm{L}$ of dd $\mathrm{H}_{2} \mathrm{O}, 2.0 \mu \mathrm{L}$ of $10 \times$ Buffer, $0.5 \mu \mathrm{L}$ of dNTPs $(10 \mathrm{mM}), 0.8 \mu \mathrm{L}$ of Forward Primer $(20 \mu \mathrm{M}), 0.8 \mu \mathrm{L}$ of Reverse Primer $(20 \mu \mathrm{M}), 0.5 \mu \mathrm{L}$ of cDNA, $0.5 \mu \mathrm{L}$ of Taq enzyme $(5 \mathrm{U} / \mu \mathrm{L})$. The thermal cycles were programmed for an initial denaturation of $3 \mathrm{~min}$ at $94{ }^{\circ} \mathrm{C}$, followed by 30 cycles of $30 \mathrm{~s}$ at $94^{\circ} \mathrm{C}, 30 \mathrm{~s}$ at $58^{\circ} \mathrm{C}$, and $45 \mathrm{~s}$ at $72{ }^{\circ} \mathrm{C}$; and a final $10 \mathrm{~min}$ extension at $72{ }^{\circ} \mathrm{C}$. Detection of PCR amplification products was performed by $1 \%$ agarose gel electrophoresis.

After electrophoresis on a $0.8 \%$ agarose gel at $300 \mathrm{~V}$ for $6 \mathrm{~min}$, the clarity and integrity of the RNA bands were visualized on a gel imager.

\section{Design of SS primers}

Based on the existing literature, we identify the SS primers (Table 1).

Table 1. Primers for SS gene amplification

\begin{tabular}{c|c|c}
\hline Primer & Length of primer (bp) & Primer sequence \\
\hline $\begin{array}{c}\text { SS-1 } \\
\text { forward primer } \\
\text { SS-1 } \\
\text { reverse primer } \\
\begin{array}{c}\text { Actin-F } \\
\text { forward primer } \\
\text { Actin-R }\end{array}\end{array}$ & 19 & GTCCCTCAAGACACTCCCT \\
reverse primer & 19 & ATTGGATTGGGCAAAGTAG \\
\hline
\end{tabular}




\section{Quantitative PCR systems and conditions}

The PCR reaction system was $25 \mu \mathrm{L}$ (TaKaRa RR820A): dd $\mathrm{H}_{2} \mathrm{O} 15.5 \mu \mathrm{L}$, $10 \times$ Buffer $2.0 \mu \mathrm{L}$, dNTPs $0.5 \mu \mathrm{L}(10 \mathrm{mM})$, F-Primer $0.8 \mu \mathrm{L}(20 \mu \mathrm{M})$, R-Primer $0.8 \mu \mathrm{L}$ $(20 \mu \mathrm{M})$, cDNA $0.5 \mu \mathrm{L}(5 \mathrm{ng} / \mu \mathrm{l})$, Taq enzyme $0.5 \mu \mathrm{L}(5 \mathrm{U} / \mu \mathrm{L})$. The PCR reaction system is: $94{ }^{\circ} \mathrm{C}$ pre-denaturation for $3 \mathrm{~min}$, followed by 30 cycles of $30 \mathrm{~s}$ denaturation at $94{ }^{\circ} \mathrm{C}, 30 \mathrm{~s}$ annealing at $58^{\circ} \mathrm{C}$, and $45 \mathrm{~s}$ extension at $72{ }^{\circ} \mathrm{C}, 72{ }^{\circ} \mathrm{C}$ extension for 10 $\min$.

\section{Detection of the expression of SS using real-time quantitative PCR}

\section{Correlation analyses of SS gene and housekeeping gene expression}

In this experiment, the relative quantitative analysis of the target gene was carried out by the Comparative Delta-delta Ct method. The correlation coefficient of the two genes measured by the experiment was required to be greater than 0.98 , and the slope of the standard curve of the two genes was less than 0.1 to achieve the use of Comparative Delta. The delta $\mathrm{Ct}$ method is used to analyze the standard of data.

\section{Real-time PCR reaction system and conditions}

Using the cDNA of 10 sweet sorghum of the same species as a template, the amplification of the target gene and the reference gene was performed, and each sample was set to 3 replicates, and a blank control was set at the same time. The PCR reaction system is $20 \mu \mathrm{L}: 10.0 \mu \mathrm{L}$ of $2 \times$ SYBR Premix ExTaq II, $6.0 \mu \mathrm{L}$ of dd $\mathrm{H}_{2} \mathrm{O}, 0.8 \mu \mathrm{L}$ of Forward Primer $(20 \mu \mathrm{M}), 0.8 \mu \mathrm{L}$ of Reverse Primer $(20 \mu \mathrm{M}), 0.4 \mu \mathrm{L}$ of ROX Reference DYE, $2.0 \mu \mathrm{L}$ of cDNA template $(5 \mathrm{ng} / \mu \mathrm{l})$. The thermal cycles were programmed for an initial denaturation of $30 \mathrm{~s}$ at $95^{\circ} \mathrm{C}$, followed by 40 cycles of $5 \mathrm{~s}$ at $95^{\circ} \mathrm{C}, 20 \mathrm{~s}$ at $60{ }^{\circ} \mathrm{C}$, and $30 \mathrm{~s}$ at $72{ }^{\circ} \mathrm{C}$.

\section{Data analysis}

Processing and analyzing experimental data were performed by using Origin (Orgin 8.6) and SPSS (IBM SPSS Statistics 21) software.

\section{Results}

\section{Analyses of extraction results of RNA}

The extracted sweet sorghum total RNA was detected by agarose gel electrophoresis, and the amplification results from left to right were: JinXi 53, sweet GL, LTR108, LTR168, HT, collier, M-81E, Rio. The strips are clear and bright, indicating that they are both good in integrity and quality during the extraction process and can be used as templates in subsequent experiments.

\section{Detection of cDNA}

Using the first strand of cDNA as a template, the target gene SS and the internal reference gene Actin were used as primers for PCR amplification. The strip is clear and bright, It has been proved that the extracted sweet sorghum RNA has been successfully converted into cDNA, and the experiment of the next fluorescent quantitative PCR can be performed. 


\section{Qualitative analyses of SS gene expression}

Simultaneous amplification of the SS gene and the housekeeping gene by real-time PCR (Corbett, Rotor-Gene-3000) was performed. The amplification curve is shown in Figures 12. The standard curve is shown in Figures 3-4. The correlation coefficient between housekeeping gene and SS gene is greater than 0.98 , indicating high correlation. The slope of the standard curve of both genes is less than 0.1. This shows that the next experiment can use the Relative Delta-delta Ct method for relative quantitative analysis.

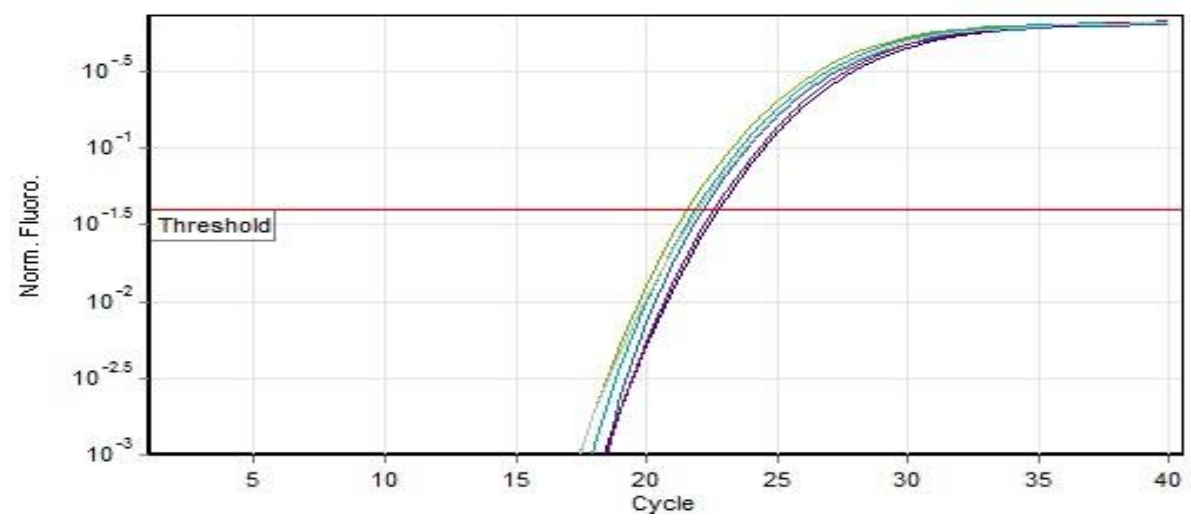

Figure 1. Real-time quantitative PCR amplification of the Actin gene

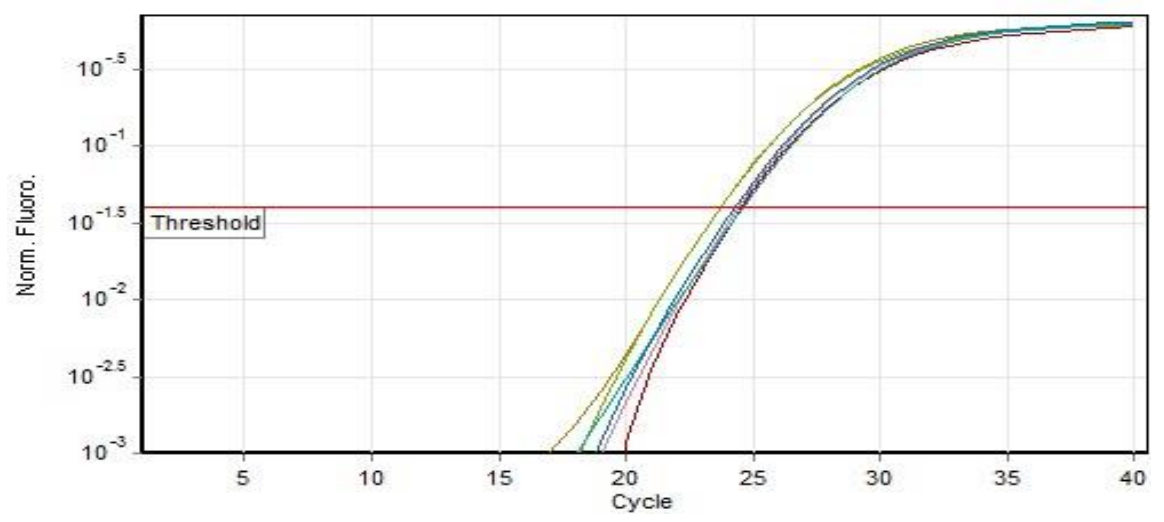

Figure 2. Real-time quantitative PCR amplification of the SS gene

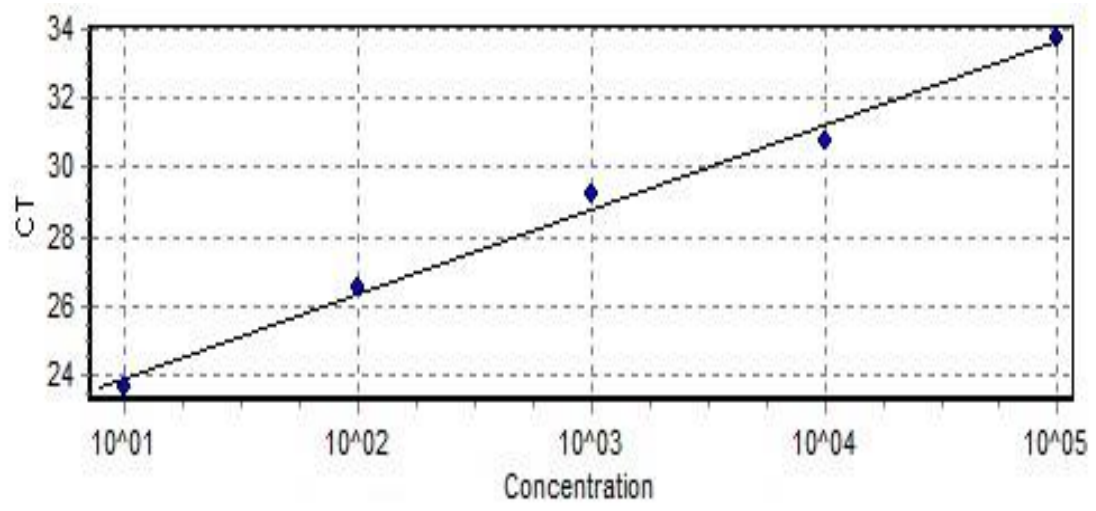

Figure 3. The standard curved of Actin gene 


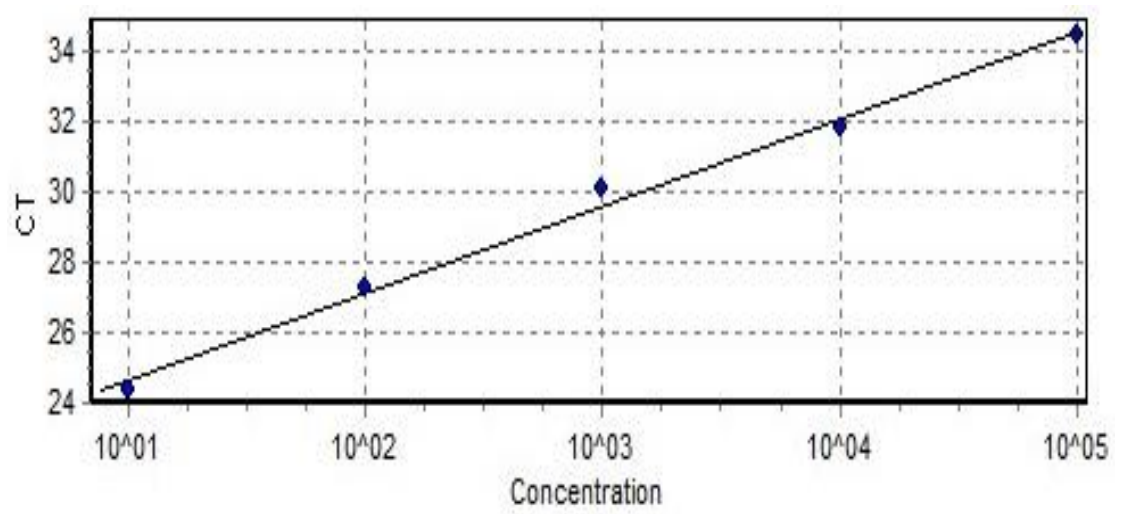

Figure 4. The standard curved of SS gene

\section{Quantitative analyses of SS gene expression}

Analysis results of the SS gene and the melting curve of the housekeeping gene are shown in Figures 5-6. It can be seen that the melting curve of the SS gene and the housekeeping gene have a single peak. It shows that during the PCR amplification process, the reaction specificity is good and the quantification is accurate. It is an ideal dissolution curve, indicating that the data of the quantitative PCR amplification in this experiment is reliable.

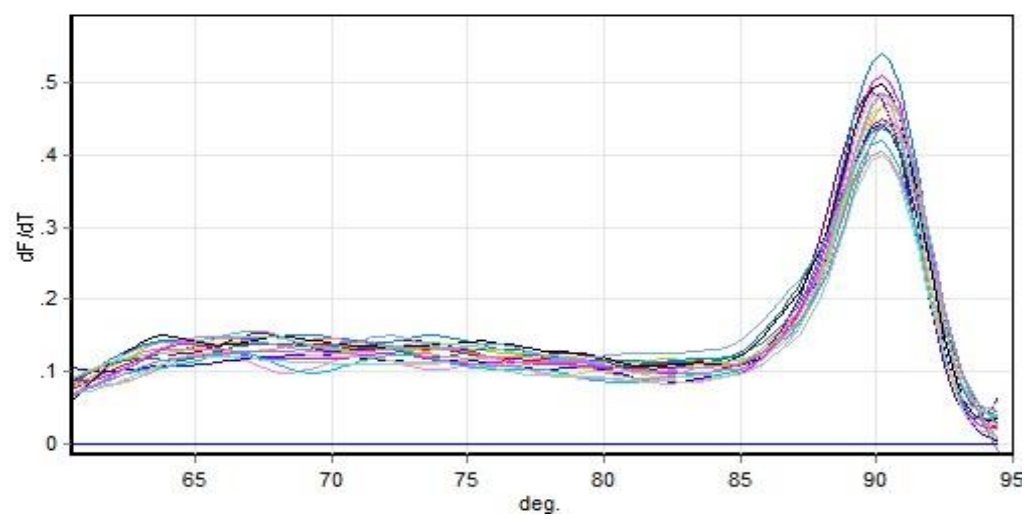

Figure 5. The melting curve of Actin gene

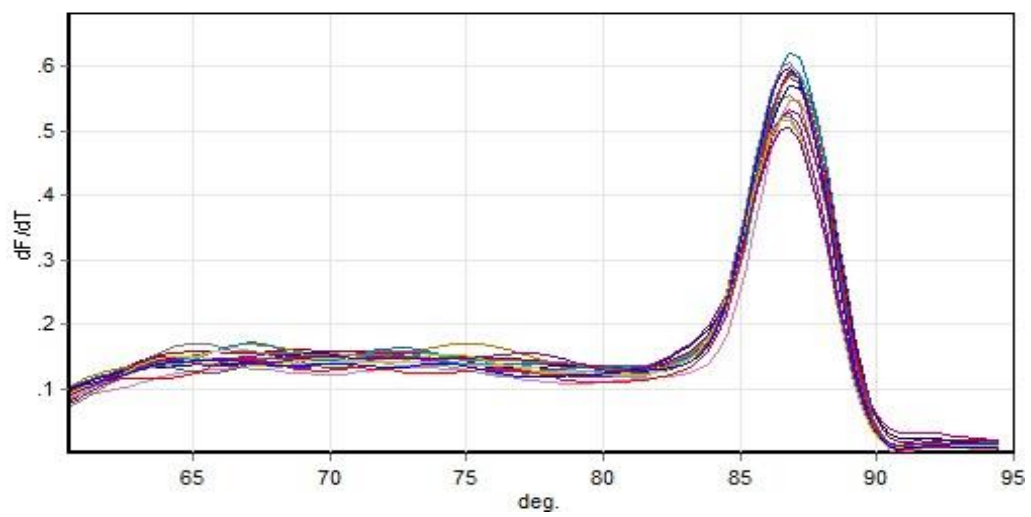

Figure 6. The melting curve of SS gene 


\section{Comparative analyses of quantitative expression of SS gene at four stages}

Fluorescence quantitative amplification experiments of SS genes in leaves of 10 varieties of sweet sorghum seedlings (Fig. 7), jointing stage (Fig. 8), heading stage (Fig. 9) and maturity (Fig. 10) was carried out then HT was selected as a comparison. Relative quantitative analysis using the Comparative Delta-delta $\mathrm{Ct}$ method found that there is a difference in the expression of the relative amounts of sweet sorghum SS in leaves of different varieties at different periods. SS is a key enzyme in sucrose metabolism. Its activity affects the synthesis of sucrose, the higher the expression of SS gene, the higher the content of sucrose.

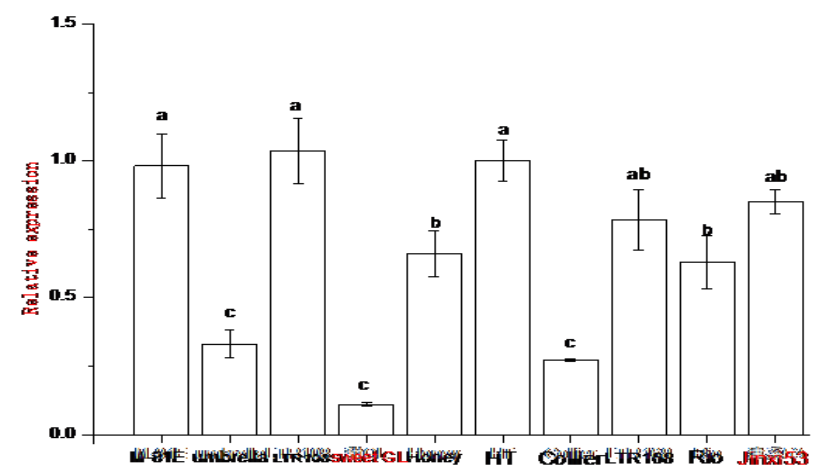

Figure 7. The comparison of different breeds of the SS gene expression in seedling stage

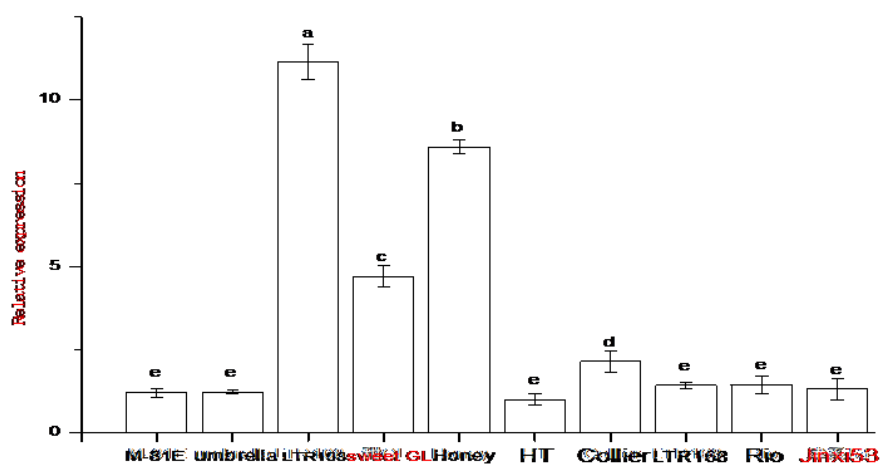

Figure 8. The comparison of different breeds of the SS gene expression in jointing stage

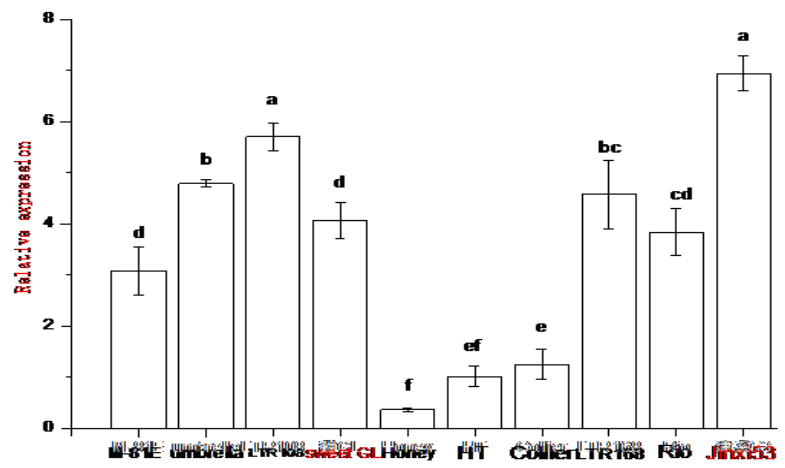

Figure 9. The comparison of different breeds of the SS gene expression in heading stage 


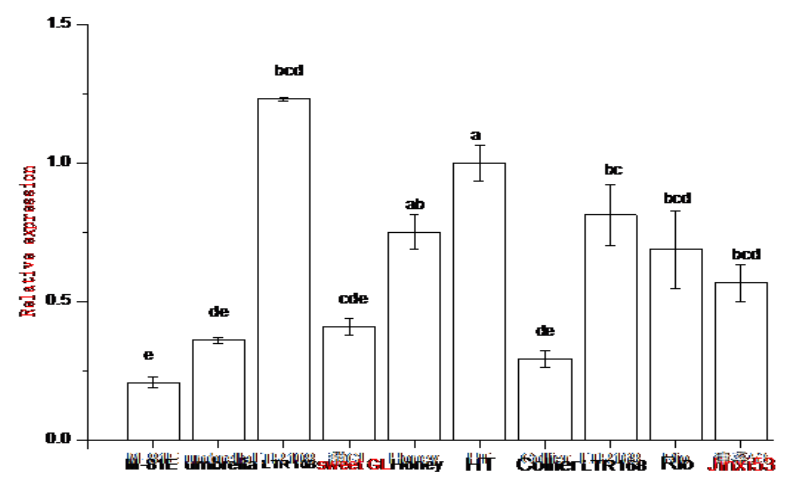

Figure 10. The comparison of different breeds of the SS gene expression in mature stage

\section{Discussion}

Sweet sorghum can be used as food, brewing, sugar and a renewable energy resource. It can be used to make ethanol (Cao et al., 2002). The accumulation of sweet sorghum stalk sugar is a very complicated process. In higher plants, sucrose is the main form of carbohydrate transport from photosynthetic source tissues to reservoir tissues. The expression of enzymes involved in its synthesis and decomposition is the main factor affecting sucrose accumulation (An, 2013).

It has many functions, including being able to participate in the synthesis of starch, cellulose and ATP, and mobilizing sucrose into various metabolic pathways, such as structural composition and storage, plant cell metabolism, etc. It is capable of reversibly synthesizing and decomposing sucrose, and regulating plants growth process, etc.

In previous studies, it was found that in the early stage of development of sweet sorghum, the expression of SS was lower, the late increase was obvious, and the heading period was the highest (Yang et al., 2009). In the analysis of SS gene expression in leaves of W452 varieties at different growth stages, the expression level of SS gene in different sweet sorghum varieties showed a trend of increasing first and then decreasing, and the flowering stage reached the highest (Xia et al., 2016).

In this experiment, RNA was extracted from 10 sweet sorghum varieties in 4 periods, and cDNA was reverse transcribed. Then, real-time quantitative PCR was used to compare the difference of SS gene expression between different varieties at different times. By comparison, it was found that the expression of SS gene was different in different periods of the same sweet sorghum variety; while the gene expression of different sweet sorghum varieties in the same period also differed. Taking a certain variety as a control and observing the expression trends of other varieties, it was found that the expression level of LTR108 was the highest in most cases in leaves, the rest of the varieties have different degrees of difference in different periods, so LTR108 varieties should be properly planted. All the varieties in the jointing stage had the highest gene expression, followed by the heading stage and it was the lowest in the seedling stage.

\section{Conclusion}

In conclusion, comparison of relative concentrations of SS genes in leaves of 10 varieties of sweet sorghum at different periods, the relative expression levels of SS gene of HT were compared with other 9 varieties in each period. There is a significant 
difference in the relative expression of SS gene among different sweet sorghum varieties. The species with the highest relative expression of the SS gene at maturity is the LTR108 variety.

Acknowledgements. The research was partly supported by Major incubating project of Shenyang Normal University.

\section{REFERENCES}

[1] An, Y. R. (2013): Study on the Expression of Sucrose Synthase Gene and Its Relationship with Sugar Content in Sweet Sorghum. - Tianjin Agricultural College, Tianjin.

[2] Cao, Y. B. (2002): Developing sweet sorghum production and exploring new ways to use energy. - Chinese Seed Industry 1: 28-29.

[3] Chai, J., Zhang, H., Yao, L. L. (2012): The role of sucrose synthase in plant growth and development. - Life Sciences 24: 81-88.

[4] Chopra, S., Del-favero, J., Dolferus, R. (1992): Sucrose synthase of Arabidopsis: Genomic cloning and sequence characterization. - Plant Mol Biol 18: 131-134.

[5] Gao, H. C., Qian, X. D., Bai, L., Pang, H. B., Li, Y. Y. (2017): Comparative study on physiological and biochemical indexes of main cultivated varieties of five kinds of sweet sorghum. - Hubei Agricultural Science 56(19): 3621-3623.

[6] Gnansounou, E., Dauriat, A., Wyman, C. E. (2005): Refining sweet sorghum to ethanol and sugar: economic tradeoffs in the context of North China. - Bioresource Technology 96: 985-1002.

[7] Hesse, H., Willmitzer, L. (1996): Expression analysis of a sucrose synthase gene from sugar beet (Beta vulgaris L.). - Plant Molecular Biology 30: 863-872.

[8] Jiang, H., Huang, J., Zhang, Y. H. (2012): Effects of salt stress on antioxidant enzyme activities in sweet sorghum seedlings. - Journal of Shenyang Normal University (Natural Science Edition) 30: 289-292.

[9] Lingle, S. E., Dyer, J. M. (2001): Cloning and expression of sucrose synthase-1 cDNA from sugarcance. - Journal of Plant Physiology 158: 129-131.

[10] Liu, C. H. (2011): Research progress and application of real-time fluorescent quantitative PCR technology. - Chinese Practical Medicine 2011: 238-240.

[11] Martin, T., Frommer, W. B., Salanoubat, M. (1993): Expression of an arabidopsis sucrose synthase gene indicates a role in metabolization ofsucrose both during phloem loading and in sink organs. - The Plant Journal for Cell and Molecular Biology 4: 367-377.

[12] Qi, H. Y., Li, T. L., Liu, H. T. (2005): Study on sugar content and related enzyme activity in different parts of tomato. - Journal of Horticulture 32: 239-243.

[13] Ren, G. M., Wang, Y. Y. (2007): Research progress of real-time fluorescent quantitative PCR. - Journal of Clinical Medicine Practice 243-245.

[14] Vermerris, W. (2011): Survey of genomics approaches to improve bioenergy traits in maize, sorghum and sugarcane free access. - Journal of Integrative Plant Biology 53: 105-119.

[15] Wu, P. H., Li, J. W., DiLi, X. T. (2016): Analysis of main biological characteristics of sweet sorghum exogenous varieties. - Shanxi Agricultural Science 8: 1127-1130.

[16] Xia, B. X., An, Y. R., Gao, J. M., Luo, F., Chen, X. M., Li, O. J., Wang, F. Y., Shi, D. F., Guan, X. N., Wu, H. Y., Pei, Z. Y. (2016): Correlation between sugar accumulation and expression of sucrose synthase gene in sweet sorghum. - Jiangsu Agricultural Science 44(2): 133-140.

[17] Xue, W., Cui, J. H., Sun, A. Q. (2009): Correlation between soluble sugar content of sorghum and SS, SPS enzyme activity. - China Agricultural Science and Technology Herald 11: 124-128. 
[18] Yang, M., Li, L. J, Li, L. Y, Wang, B., Chang, J. H., Liu, G. Z. (2009): Correlation analysis between sucrose synthase expression and sucrose accumulation in sweet sorghum. - Crop Journal 35(1): 185-189.

[19] Ye, K., Kuerban, Z., Chen, W. W. (2012): Study on the activity of SS and SPS enzymes of sweet sorghum straw under different sowing periods. - Xinjiang Agricultural Science 2012: 1874-1880.

[20] Yu, H. L., Shi, Z. S., Cong, L. (2014): Comparison of photosynthesis and physiological responses of sweet sorghum and sorghum under drought stress. - Jiangsu Agricultural Science 2: 72-75.

[21] Zhan, X., Wang, D., Tuinstra, M. R. (2003): Ethanol and lactic acid production as affected by sorghum genotype and location. - Industrial Crops and Products 18: 245-255.

[22] Zhang, C. H., Yu, M. L., Ma, R. J. (2014): Dynamic changes of main carbohydrate content and sucrose synthase gene expression level in different developmental stages of peach. - Jiangsu Journal of Agricultural Sciences 6: 1456-1463.

[23] Zhang, S. J., Amej, W., Xue, X. Z. (2014): Analysis of silage quality of maize and sweet sugar sorghum in southern Xinjiang. - Journal of Grass Industry 23: 232-240.

[24] Zhao, H., Zhai, G. W., Zou, G. H. (2015a): Comparison of the changes in the distribution of material accumulation between sweet sorghum and common sorghum. - Zhejiang Agricultural News 1: 7-11.

[25] Zhao, Y. Y., Xu, H., Lu, Z. H. (2015b): Advances in research on energy traits and stress resistance mechanism of sweet sorghum under saline-alkali and drought stress. - Journal of Jiangxi Agricultural University 1: 54-59. 